\title{
Bykov Yu. \\ DEVELOPMENT OF IMPLICIT METHOD FOR NUMERICAL MODELING OF TURBOMACHINE BLADE THERMOELASTIC VIBRATIONS
}

В останні десятиліття спостерігається тенденція до підвищення температури згоряння палива в газотурбінних двигунах (ГТД). Це дозволяє підняти як ефективність роботи двигуна, так і вихідну потужність. У сучасних двигунах температури відпрацвованих газів вже істотно перевищують температуру плавлення матеріалу лопаток. У зв'язку з иим при проектуванні турбін ГТД виникає необхідність в застосуванні чисельних методів, які дозволяють найбільи достовірно моделювати нестаціонарні аеротермопружні ефекти. Однією із складових частин задачі аеротермопружності є інтегрування нестаціонарних рівнянь термопружності спільно з рівняннями аеродинаміки. Оскільки ці рівняння повинні вирішуватися спільно з єдиним кроком за часом, необхідно віддавати перевагу неявним чисельним методам інтегрування. Об'єктом дослідження є нестаціонарна взаємодія термопружних коливань лопаток турбіни та потоку газу.

У даній роботі представлений неявний чисельний метод моделювання термопружних коливань елементів конструкиї турбіни ГТД, в тому числі лопаток турбіни, обладнаних каналами охолодження. В основі методу покладено рівняння лінійної термопружності, які інтегруються методом кінцевих елементів. Досліджувана область розбивається на комірки, що утворюють розрахункову сітку з гексаедрами з додатковими вузлами. Розрахункові вузли вибираються таким чином, щоб на один елемент припадало 20 вузлів. Апроксимація параметрів в елементі виконується за допомогою поліномів третього ступеня. Інтегрування за часом проводиться також з третім порядком точності.

Показані результати тестування методу на модельних задачах, а також порівняння результатів моделювання коливань лопатки стандартної конфігураџї з результатами інших авторів. Розбіжність результатів не перевищує 0,4\% для модельної задачі і 0,7\% для коливань лопатки. Отримані результати свідчать про те, що представлений метод можна використовувати для чисельного моделювання нестаціонарних термопружних коливань елементів конструкцї газотурбінного двигуна.

Ключові слова: чисельні методи, теорія пружності, динаміка лопаток турбомашин, аеротермопружність, газотурбінний двигун.

\section{Introduction}

The most common way to increase the efficiency of modern gas turbine engines is to increase the temperature at the inlet to the first stages of the turbine. The reason for using high temperatures lies in the increase in pressure for the adiabatic expansion process, therefore, in the possibility of creating greater specific work when expanding the gas in the turbine. Today, the inlet temperatures of the gas turbine impeller have reached a level far exceeding the melting temperature of the turbine material. The problem of determining the level of dynamic and thermal stresses in turbine blades is too complicated for experimental studies, therefore, by introducing modern methods and means of numerical modeling into practice, it is possible to significantly reduce the cost of an experimental search for optimal materials and modes of efficient operation of the turbine. That is, an urgent problem is the numerical simulation of the interaction of the streamlined flow and the vibrations of the blades, taking into account the significant temperature unevenness and the complex design of the blades in the first stages of gas and steam turbines.

The importance of taking into account the temperature distribution and the interaction of the blade with the flow is confirmed by studies of other authors [1]. It is also necessary to take into account the complex design of the blade equipped with cooling. The solution to this problem is to integrate the thermoelasticity equations. To date, various models are used to solve the problem:

- model of thin shells [2, 3];

- model of a thin plate with variable thickness [4];

- model of vibrations of the blade taking into account the spatial shape of the blade [5, 6].

For this problem, the most suitable model is the model of blade vibrations taking into account the spatial shape and material, since it allows taking into account both the design of the blade and the uneven temperature and properties. There are several solutions for this model, including the modal approach $[5,6]$ and the method of direct 
integration of the equations of motion [7]. The modal approach consists in finding a solution in the form of a linear combination of the eigenmodes of vibration of the blade, the coefficients of which depend on time and are calculated at each time step. The general problem of flow around the crown blade and blade vibrations using the modal method is considered in [8]. The disadvantage of this method is the need to re-determine the eigenmodes and frequencies when changing the physical properties of the material of the blade, in terms of computational costs, it can be less effective than with direct integration of the equations of motion. Thus, the most suitable method for modeling blade vibrations in this problem is the method of direct integration of the equations of motion. The main method for solving the problem of thermoelasticity is the finite element method $[9,10]$.

Thus, the object of research is the unsteady interaction of thermoelastic vibrations of the turbine blades and gas flow. The aim of research is development of an effective method and software for the numerical simulation of thermoelastic vibrations of turbine engine blades.

\section{Methods of research}

2.1. Source equations. Vibrations of a turbomachine blade are described by dynamic thermoelastic equations for a solid in three spatial dimensions [11-13]:

$$
\begin{aligned}
& \rho \frac{\partial^{2} \vec{u}}{\partial t^{2}}=(\lambda+\mu) \nabla \operatorname{div} \vec{u}+\mu \Delta \vec{u}+\rho \vec{f}-\gamma \operatorname{grad} \theta \\
& \frac{1}{\chi} \frac{\partial \theta}{\partial t}=\Delta \theta-\eta \frac{\partial}{\partial t} \operatorname{div} \vec{u}+\frac{Q}{\chi}
\end{aligned}
$$

where $\vec{u}$ - displacement vector of the coordinates of the point in the body; $\rho$ - density; $\vec{f}$ - vector of mass forces;

$$
\mu=\frac{E}{2(1+v)}, \quad \lambda=\frac{v E}{(1+v)(1-2 v)}
$$

- Lamé coefficients; $E$ - Young's modulus; $v$ - Poisson's ratio; $\gamma=(3 \lambda+2 \mu) \alpha ; \alpha-$ coefficient of linear thermal expansion; $\theta=T-T_{0}$ - temperature deviation; $\chi$ - coefficient of thermal diffusivity; $\eta=\gamma T_{0} / k ; k$ - coefficient of thermal conductivity; $Q$ - heat source.

Equations (1) are supplemented by the boundary conditions on the surfaces of the blade:

- in the root section $\vec{u}=0$;

- on the surface:

$$
\sigma_{i j} n_{j}=p_{i}
$$

where $\sigma_{i j}$ - stress tensor; $n_{j}$ - vector normal to the surface; $p_{i}$ - vector of external forces.

For $\theta$, a value is set at the boundaries of the body $\theta=\theta_{w}$, or heat flux

$$
\frac{\partial \theta}{\partial n}=\left.\frac{\partial \theta}{\partial n}\right|_{w} .
$$

In the case of interaction with the surrounding fluid, the vector of external forces is defined as $p_{i}=p n_{i}$ ( $p$ is the fluid pressure). Equation (1) is also supplemented by the initial conditions:

$$
\vec{u}=\vec{u}_{0}(x), \quad \frac{\partial \vec{u}}{\partial t}=\vec{u}_{1}(x), \quad \theta=\theta_{0}(x) .
$$

2.2. Numerical simulation method. There are various methods for the numerical integration of equations (1). Among the most common, the method of finite differences, finite volumes, and finite elements is used [9, 10]. The finite difference method requires the use of generalized coordinates, complicates the equation. The finite volume method for obtaining acceptable results requires the use of high-order approximations. At the same time, the finite element method provides an efficient algorithm that allows applying approximation of various orders on different computational grids. In this paper, let's apply the finite element method, built on the use of third-degree elements on a grid with a hexahedron.

At each time step, elastic forces are calculated at the nodes of the computational grid for each cell according to the formula [10]:

$$
\mathbf{r}=\left[\int_{\Omega}\left(\mathbf{B}^{T} \mathbf{D B}\right) \mathrm{d} \Omega\right] \delta-\int_{\Omega} \mathbf{N}^{T} \mathbf{f}^{e} \mathrm{~d} \Omega,
$$

where $\mathbf{r}$ - vector containing the components of the force vectors of the vertices of the cell; $\delta$ - vector containing the components of the displacement vectors of the cell vertices; $\mathbf{f}^{e}$ - vector of mass forces in the cell; $\mathbf{B}$ - transformation matrix of the displacement vector $\delta$ into a vector containing the components of the strain tensor $\varepsilon, \varepsilon=\mathbf{B} \delta ; \mathbf{D}$ - transformation matrix of the vector $\varepsilon$ into a vector containing the components of the stress tensor $\sigma, \sigma=\mathbf{D} \boldsymbol{\varepsilon} ; \mathbf{N}$ - transformation matrix of the vector $\delta$ into the displacement vector inside the cell $\mathbf{u}^{e}$, $\mathbf{u}^{e}=\mathbf{N} ; \Omega-$ cell volume.

Next, the integration of the equation of motion of the grid nodes is performed:

$$
\rho \frac{\partial^{2} \mathbf{u}_{i}}{\partial t^{2}}=\sum_{j} \mathbf{R}_{i} \mathbf{r}_{j},
$$

where $\mathbf{R}_{i}$ - transformation matrix of the components of the vector $\mathbf{r}$ into the components of the force vector of the $i$-th node of the computational grid; $\mathbf{u}_{i}$ - displacement vector of the $i$-th node, the summation is carried out over all cells of the computational grid.

For the numerical integration of equations (1), a combination of previously developed methods is used. The equation for temperature is integrated by the method of finite volumes of the second order in spatial coordinates described in [14]. The equations of motion are integrated by the finite element method, which can be obtained by modifying the method described in [15].

The hexagonal cell of the computational grid is selected as the finite element. The approximation of variables by an element is performed using a polynomial of the third degree:

$$
u=\sum_{i, j, k=0}^{3} a_{i j k} x^{i} y^{j} z^{i} .
$$

The matrix $a_{i j k}$ has twenty nonzero elements, that is, for approximation, the values of variables at 20 points of each cell are used. 
Thus, the equation of motion (1) after discretization by the nodes of the computational grid and time steps turns into a system of linear equations:

$$
\begin{aligned}
& B u_{n}=5 u_{n-1}-4 u_{n-2}+u_{n-3}+F, \\
& B=\left(2-\Delta t^{2} A\right),
\end{aligned}
$$

where $\Delta t$ - time step; $n$ - time step number; $u_{n}$ - vector of displacements in the nodes of the computational grid; $F-$ vector of external forces.

Implicit discretization of the equations of motion (2) provides a third order of approximation with respect to spatial variables and time and is absolutely stable at any values of the Courant number. The matrix $B$ of equations (2) does not have dominant diagonals, which limits the use of iterative methods, does not allow splitting in coordinates, and is too large for direct inversion methods. Therefore, to solve equations (2), the following approximation is proposed:

$$
B^{-1}=\left(\sum C_{i} B_{i}\right)^{-1} \approx \sum C_{i} B_{i}^{-1},
$$

where $B_{i}-$ matrix of equations (2) for one cell with number $i ; C_{i}$ - corresponding matrix of the connection of the nodes of cell $i$ with other cells. This matrix has a dominant unit main diagonal $\left(\left(C_{i}\right)_{i j}=1\right)$.

Matrices $B_{i}$ are rotated using the classical Gauss-Jordan method. The integration of equations (1) is carried out jointly using the same time step.

\section{Research results and discussion}

As the first test object of the numerical method, a beam of $1 \mathrm{~m}$ square $0.05 \mathrm{~m} \times 0.05 \mathrm{~m}$ in length, rigidly fixed at one end and free at the other, was chosen. The beam volume was divided into identical rectangular hexagonal cells, forming a computational grid of size $30 \times 1 \times 1$. As the initial condition, a bend along one of the coordinate planes corresponding to one of the first 4 eigenmodes of bending vibrations of the beam was chosen [16]. As a result, the vibration frequencies are obtained corresponding to the chosen eigenmodes. Table 1 presents the theoretical [16] and calculated values of the eigenfrequencies for the given characteristics of the beam material: Young's modulus $E=2.1 \cdot 10^{8} \mathrm{~Pa}$; Poisson's ratio $v=0.3$; density $\rho=7.8 \cdot 10^{3} \mathrm{~kg} / \mathrm{m}^{3}$.

Table 1

Eigenfrequencies of bending vibrations of the beam

\begin{tabular}{|c|c|c|c|c|}
\hline Mode & 1 & 2 & 3 & 4 \\
\hline Frequency (theory), $\mathrm{Hz}$ & 23.549 & 147.595 & 413.313 & 809.946 \\
\hline Frequency (calculation), $\mathrm{Hz}$ & 23.584 & 146.863 & 412.095 & 806.731 \\
\hline
\end{tabular}

The average difference between theoretical and calculated data does not exceed $0.4 \%$. The torsional vibration frequencies of the beam of the first 4 eigenmodes were also obtained. The results are presented in Table 2 .

The average difference of the presented data for torsional vibrations does not exceed $0.16 \%$.
Table 2

Eigenfrequencies of torsional vibrations of the beam

\begin{tabular}{|l|c|c|c|c|}
\hline \multicolumn{1}{|c|}{ Mode } & 1 & 2 & 3 & 4 \\
\hline Frequency (theory), $\mathrm{Hz}$ & 257.7 & 773.2 & 1288.7 & 1804.1 \\
\hline Frequency (calculation), $\mathrm{Hz}$ & 257.6 & 775.1 & 1288.1 & 1798.8 \\
\hline
\end{tabular}

The second object was a turbine blade of the last stage of a steam turbine with characteristic dimensions: height $h=0.775 \mathrm{~m}$; the chord in the root section $c=0.11 \mathrm{~m}$, in the peripheral section $-c=0.0945 \mathrm{~m}$. For this blade, the eigenmodes and eigenfrequencies of elastic vibrations were determined by a third-party method [17] for the clamping conditions at the root and free end of the blade. As an initial condition, one of 5 eigenmodes was chosen, for which the corresponding eigenfrequency was determined. The computational $\mathrm{H}$-grid was an $8 \times 38 \times 1$ : 8 rows uniformly in height, 38 rows along the chord, 1 row in thickness. Table 3 presents the initial and calculated values of the eigenfrequencies for the given characteristics of the material of the blade: Young's modulus $E=2.1 \cdot 10^{8} \mathrm{~Pa}$; Poisson's ratio $v=0.3$; density $\rho=7.8 \cdot 10^{3} \mathrm{~kg} / \mathrm{m}^{3}$.

Table 3

Eigenfrequencies of the blade

\begin{tabular}{|l|c|c|c|c|c|}
\hline \multicolumn{1}{|c|}{ Mode } & 1 & 2 & 3 & 4 & 5 \\
\hline Frequency ([17]), Hz & 41.263 & 99.109 & 216.320 & 220.832 & 320.555 \\
\hline $\begin{array}{l}\text { Frequency } \\
\text { (calculation), } \mathrm{Hz}\end{array}$ & 41.563 & 98.815 & 216.005 & 221.626 & 319.582 \\
\hline
\end{tabular}

The average relative difference between the data for blade vibrations in the Table 3 does not exceed $0.7 \%$.

\section{Conclusions}

A method and software for numerical modeling of thermoelastic vibrations of a turbomachine blade with a higher approximation order are developed. The results of numerical modeling of elastic vibrations of various bodies of complex shape are presented. They demonstrate sufficient efficiency and accuracy of the developed numerical method. This method allows the use of sophisticated models of turbomachine blades. Further development of the method for solving the problems of thermoelasticity allows its use to solve the problem of aerothermoelastics of turbomachines.

\section{References}

1. Vorobev, Iu. S., Diakonenko, K. Iu., Kulishov, S. B., Skrickii, A. N. (2009). Vliianie temperaturnoi neodnorodnosti na kolebaniia okhlazhdaemykh monokristallicheskikh lopatok gazovykh turbin. Vestnik dvigatelestroeniia, 3, 140-143.

2. Miroshnichenko, S. T., Pukhlii, V. A. (2009). K raschetu centrobezhnykh nasosov v iadernoi energetike. Sbornik nauchnykh trudov SNUIAEtaP, 3, 31-40.

3. Grinberg, S. M. (1969). K raschetu chastot kolebanii lopatok kompressora metodami teorii obolochek. Prochnost $i$ dinamika aviacionnykh dvigatelei, 5, 242-255.

4. Bendiksen, O. O. (1998). Nonlinear Blade Vibration and Flutter in Transonic Rotors. Proc. of ISROMAC-7, 664-673. 
5. Moyroud, F., Jacquet-Richardet, G., Fransson, T. H. (2000). Aeroelasticity in Turbomachines: Some Aspects of the Effect of Coupling Modeling and Blade Material Changes. International Journal of Rotating Machinery, 6 (4), 265-273. doi: http:// doi.org/10.1155/s1023621x00000257

6. Gnesin, V. I., Kolodiazhnaia, L. V. (2009). Chislennii analiz vliianiia sootnosheniia chisel lopatok statora i rotora na nestacionarnye nagruzki i rezhimy kolebanii lopatok. Vestnik $N T U$ «KHPI». Seriia: Energeticheskie i teplotekhnicheskie processy $i$ oborudovanie, 3, 23-32.

7. Vorobev, Iu. S., Chernobryvko, M. V., Chugai, M. A., Romanenko, V. N. (2010). Problemy chislennogo analiza dinamiki elementov sovremennykh konstrukcii. Vestnik SevNTU, 110, 20-25.

8. Gnesin, V. I., Kolodiazhnaia, L. V., Zhandkovski, R. (2009). Aerouprugoe povedenie poslednei stupeni turbomashiny na nominalnom i chastichnom rezhimakh $\mathrm{v}$ trekhmernom potoke viazkogo gaza. Problemy mashinostroeniia, 12 (6), 8-18.

9. Koltunov, M. A., Kravchuk, A. S., Maiboroda, V. P. (1983) Prikladnaia mekhanika deformiruemogo tverdogo tela. Moscow: Vysshaia shkola, 349

10. Pobedria, B. E. (1995). Chislennye metody v teorii uprugosti $i$ plastichnosti. Moscow: Izd-vo MGU, 366.
11. Kupradze, V. D. (1976). Trekhmernye zadachi matematicheskoi teorii uprugosti i termouprugosti. Moscow: Nauka, 664.

12. Kovalenko, A. D. (1975). Termouprugost. Kyiv: Vischa shkola, 216

13. Novackii, V. (1970). Dinamicheskie zadachi termouprugosti. Moscow: Mir, 256.

14. Bykov, Yu. A. (2009). Chislennoe modelirovanie techeniia v reshetke kolebliuschikhsia profilei s uchetom teploobmena. Problemy mashinostroeniia, 12 (5), 36-41.

15. Bykov, Yu. A., Gnesin, V. I. (2011). Numerical simulation of elastic vibrations of turbomachinery blades. Eastern-European Journal of Enterprise Technologies, 3 (7 (51)), 62-65. Available at: http://journals.uran.ua/eejet/article/view/1631

16. Babakov, I. M. (1968). Teoriia kolebanii. Moscow: Nauka, 560

17. Bykov, Yu. A., Gnesin, V. I. (2011). Chislennoe modelirovanie termouprugikh kolebanii lopatok turbomashin. Vestnik $N T U \ll K H P I »$, 33, 43-47.

Bykov Yuri, PhD, Department of Hydroaeromechanics of Power Machines, A. Podgorny Institute of Mechanical Engineering Problems of National Academy of Sciences of Ukraine, Kharkiv, Ukraine, e-mail: yubykoff@gmail.com, ORCID: http://orcid.org/0000-00017089-8993 